\title{
Continued rapid growth and the turning point in China's development
}

\section{Ross Garnaut and Yiping Huang}

China's rapid economic growth continued strongly over the past year. Earlier concerns about overheating and inflationary pressures have eased, despite some acceleration of growth. The debate about whether China's unprecedented investment share of GDP is consistent with sustained rapid growth has subsided somewhat, although policymakers are still concerned about risks of overcapacity in certain industries as the investment share is a bit higher this year than last. There is increasing recognition that current or moderately higher investment shares could be sustained for long periods, and also that, sooner or later, consumption must grow much more strongly than over the past decade. The rate of growth in consumption has in fact increased over the past year. The small currency appreciation and change towards a more flexible exchange rate regime in mid 2005 has been followed by a small additional appreciation, and a sharp increase in China's trade and current account surpluses and in the level of foreign exchange reserves. It is now clear that a large deficiency in real domestic expenditure relative to rapidly growing productive capacity requires early correction.

Over the past year there have been stronger signs of emerging scarcity of labour, especially in the rapidly growing and relatively rich coastal provinces. The signs include rates of increase in real wages_-high by historical standards in China or elsewhere. These lead us to ask whether China has reached what in the literature has been called 'the turning point in economic development' (see Chapter One, this volume). Chinese economic growth in the reform era has been associated with the transfer of large amounts of labour from agriculture to non-agricultural 
employment, increasingly from rural to urban areas. At first, the presence of large amounts of 'surplus labour' in the countryside made rapid growth in demand for unskilled labour in industrial and a range of urban employment consistent with relatively stable wages in rural areas and towns. This supported continuing competitiveness of labour-intensive export industries.

Has the growth in labour demand pushed China into the 'turning point', at which surplus labour is no longer available, and at which continued rapid growth is associated with large and continuing increases in labour costs? If so, how will this affect the structure of the Chinese economy and its interaction with the international economy, and China's prospects for sustaining growth? We take up these important questions later in the chapter.

\section{Overview of macroeconomic development}

China continued its remarkable macroeconomic performance during the past year. While economic growth gradually accelerated, inflation remained very mild (Figure 2.1). Quicker pace of GDP expansion during recent quarters, rising from 9.8 per cent in the third quarter of 2005 to 11.3 per cent in the second quarter of 2006, caused some concerns about overheating risks. However, the unusually low CPI, staying consistently below 1.5 per cent during the past four quarters, did not appear to support the case for drastic policy tightening. Economists and government officials are divided on the inflation outlook. Some warn that deflation is the key risk as the overinvestment problem continues to deteriorate, while others fear that inflation rates will rise rapidly, fuelled by increasing wage rates and high commodity prices.

Composition of GDP evolved further (Figure 2.2). Consumption, especially private consumption, shrank further in relative terms. Share of investment edged up to 43.4 per cent in 2005 from 43.2 per cent in 2004. More importantly, the share of net exports rose to 4.5 per cent from 2.5 per cent. In fact, net exports contributed more than half of GDP growth in 2005. The current account surplus equalled 7.1 per cent of GDP in 2005, compared with 3.5 per cent in the previous year. Remarkably, these data imply that China's national saving rate had come to exceed 50 per cent.

From the beginning of 2006, especially following implementation of the $11^{\text {th }}$ Five-Year Plan, the authorities stepped up efforts to rebalance economic growth, with increasing consumption relative to investment and increasing domestic demand relative to external demand. Policymakers took steps to consolidate industries with high risks of overcapacity, to caution commercial banks on loan expansion and to tighten monetary conditions in order to cool down investment. 
Figure 2.1 Quarterly real GDP growth and inflation in China, 2000-06 (per cent year/year)

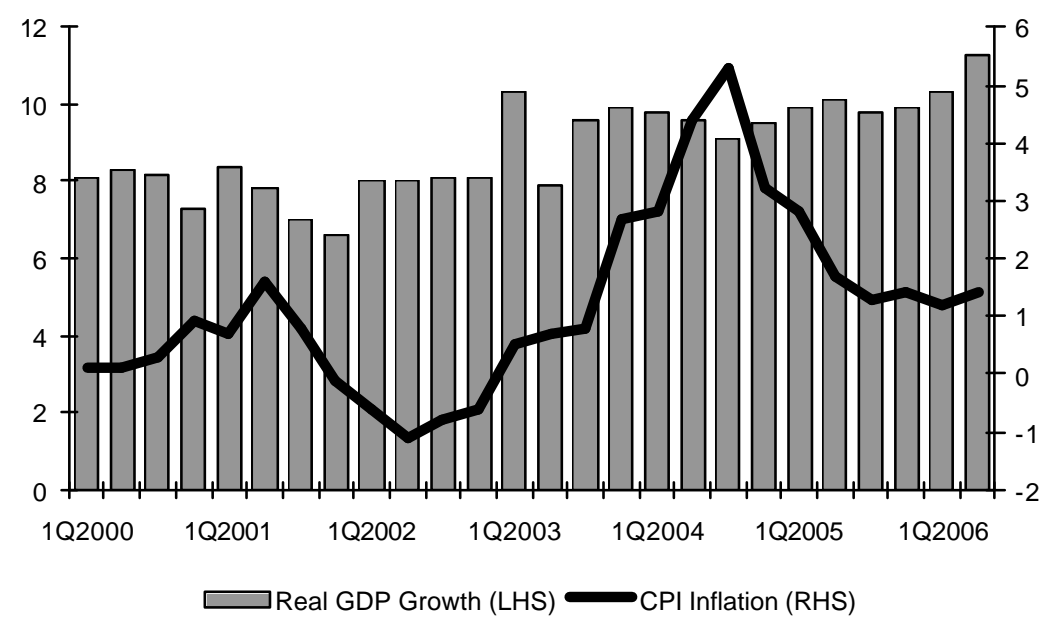

Source: CEIC Data Company.

Figure 2.2 Changing composition of GDP, 2000-05 (per cent of GDP)

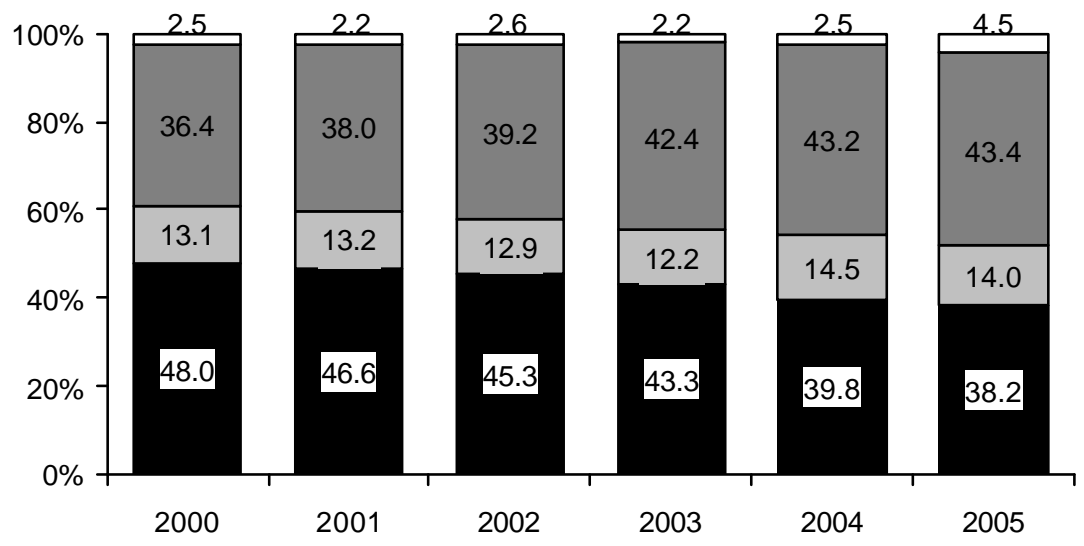

$\square$ Household Consumption $\square$ Public Consumption

$\square$ Gross Capital Formation $\square$ Net Exports

Source: CEIC Data Company. 
They also sought to stimulate private consumption, by increasing the threshold for personal income tax, abolishing agricultural taxes and encouraging development of easier access to consumer credit.

However, the ratios that have been the concern of policymakers have not moved in the preferred directions. Fixed-asset investment grew by 31.3 per cent in the first half of 2006, compared with 27.2 per cent in 2005, and growth accelerated in recent months (Figure 2.3). Consumer spending accelerated slightly, but its growth remained lower than investment.

Both export and import growth rates fell somewhat, but the trade surplus expanded. It was 54.9 per cent higher in the first half of 2006 than in the corresponding period of the preceding year (Figure 2.4). This, together with continued inflows of foreign direct investment and other capital, contributed to rapid accumulation of foreign exchange reserves, which increased by US $\$ 123$ billion during the first six months of 2006. At US\$941 billion at the end of June 2006, China's reserves were the largest in the world.

Macroeconomic policies began to shift towards modest tightening bias from the beginning of the year. Calls for further tightening intensified following publication of very strong second quarter economic data. The People's Bank of China (PBOC) quickly raised the reserve requirement ratio by another 50 basis points, only a month after the first hike and three months after increase in base lending rates by an average of 27 basis points. These policy measures caused some renewed fear in international financial markets of rapid slowdown of the Chinese economy, with significant implications for the rest of the world, especially the global commodity markets. As with similar concerns over recent years, they will be disappointed.

So far, the policy tightening has been modest and selective. It is possible that the authorities may introduce more tightening policies, but it is very unlikely that the economy would slow significantly. With a savings ratio of around 50 per cent, a slowing of investment would not serve a good macroeconomic purpose at this time.

Given that investment continues to grow much faster than consumption, to many government officials and investors overcapacity is the key risk. In March, the State Council issued an official document addressing the concern about overcapacity in some sectors. It specifically claimed that the iron and steel, electrolysis aluminum, calcium carbide, iron alloy, coke and automotive sectors had already suffered overcapacity problems while the cement, coal, power and textile sectors could see overcapacities soon.

Interestingly, overcapacity risks are likely to be larger in industries dominated by the state sectors (Figure 2.5). In the coal mining and power sectors, for instance, 
Figure 2.3 Growth of fixed-asset investment and retail sales, January 2000-June 2006 (per cent year/year)

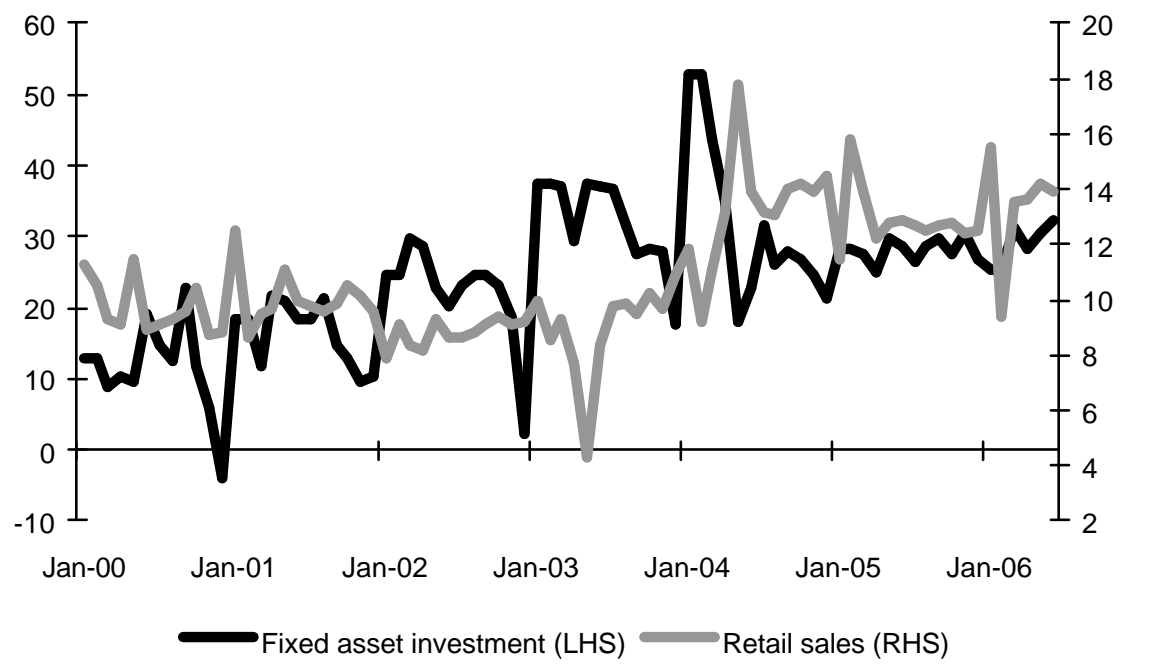

Source: CEIC Data Company.

Figure 2.4 Growth of exports and imports, January 2000-June 2006 (per cent year-on-year)

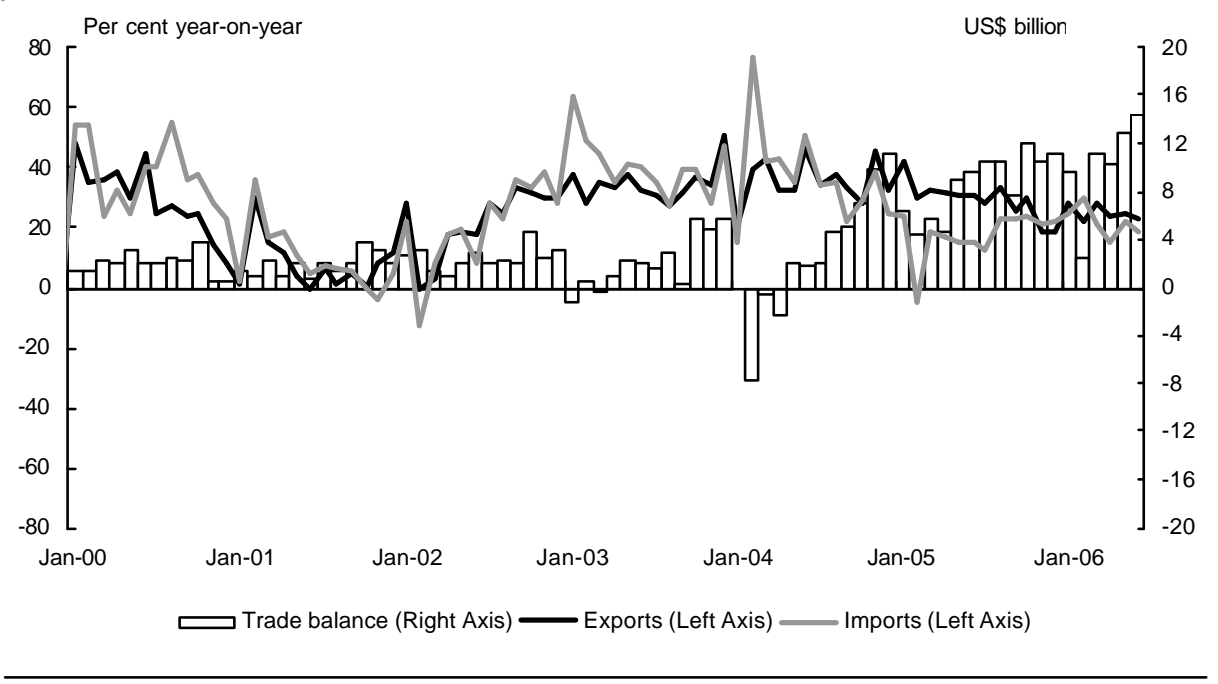

Source: CEIC Data Company. 
shares of the state sector in total assets are well above 80 per cent. The only two sectors with even higher state sector shares are tobacco and extraction of oil and gas.

More importantly, for an open and dynamic economy like China, there are many tricks in the definition of overcapacity. While the government has successively warned about overcapacity risks in electronics, personal computers, mobile phones, automobiles, and building materials over the past ten years, most excess capacity appears to be temporary, and rapidly growing demand including the expansion of exports has quickly absorbed the so-called overcapacity.

\section{The turning point in economic development?}

When economic reforms began in the late 1970s, China enjoyed significant potential comparative advantages in labour-intensive activities. It was the world's most populous country with a total population of close to 1 billion. In 1978, more than 80

Figure 2.5 Share of state sector in total assets for selected industries, 2005 (per cent)

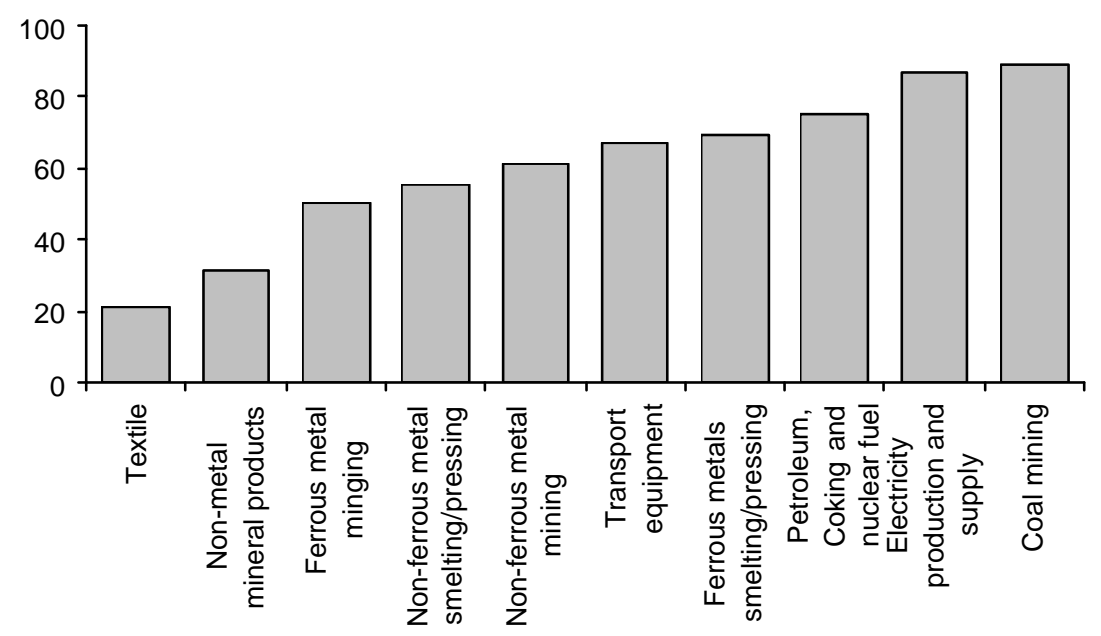

Source: National Statistics Bureau of China and Citigroup estimates. 
per cent of the population was involved in the agricultural sector and most of these workers were underemployed. Arable land area per agricultural worker was less than one hectare, only about 10 per cent of the world's average.

The serious underemployment problem in the agricultural sector and potential productivity gain from transferring labour from agriculture to the non-agricultural sector offer a live case of the Lewis dual sector development model (Lewis 1954). The model assumes that developing countries have dual economies with both a traditional agricultural sector and a modern industrial sector. As labour productivity is so low in traditional agricultural areas people leaving the rural areas would have virtually no impact on output. The 'capitalist' industrial sector develops by drawing labour from a non-capitalist 'subsistence' agricultural sector. The existence of 'surplus labour' in the subsistence sector ensures that during an extended period of rapid modern sector growth, wages remain steady, because the supply of labour to the modern sector exceeds demand at this wage rate. The surplus of output over wages is captured by the owners of businesses as profit.

Development in China was broadly consistent with the insights from the Lewis model during the first twenty-five years of China's economic reform. From the mid 1980s, surplus labour moved to rural non-agricultural activities established by large number of township and village enterprises (TVEs). By 1990, rural nonagricultural employment had already reached 109 million, which was about 23 per cent of the total rural labour force. This number further increased to 185 million in 2005 , or 38 per cent of the rural labour force.

From the early 1990s, as urban reforms and growth gathered momentum, farmers began to move into the cities for employment in manufacturing, construction and service industries. This happened despite the official household registration system (HRS) continuing to restrict labour mobility. By 2004, the total number of migrant workers in the cities had risen to over 100 million. ${ }^{1}$

Continuous supply of vast numbers of unskilled workers at very low wages fuelled boom in the labour-intensive industries in China. The unusually low labour costs pushed up returns on capital, enhanced Chinese products' international competitiveness and improved most companies' cash flows. Cheap labour and huge domestic market potential are the top two reasons most commonly identified as attractions for foreign investors into China. ${ }^{2}$

In recent years, however, much of the coastal region was surprised by the emergence of labour shortages. This raised the questions of whether the 'unlimited' supplies of labour had come to an end, and whether China had reached a turning point in economic development at which rising wages begin to undermine 
competitveness of labour-intensive industry, and at an extreme whether the associated reductions in returns on investment would reduce the rate of capital accumulation and economic growth.

The turning point in China's economic development can have very important implications for China's economic structure and also for global markets. Faster growth of wage rates following the conclusion of the era of 'unlimited' supplies of labour, for instance, could eventually increase consumption, force major appreciation of the real exchange rate (either through currency appreciation or inflation), squeeze profit margins, force industrial upgrading, shift China's export specialisation away from labour-intensive products, and raise export prices. China's comparative advantage could be expected to shift to more capital or technologyintensive sectors. This would also induce further global restructuring.

Has China, after a quarter century of reform and rapid growth, arrived at the turning point? We first take a quick look at the latest labour shortages in China. We then examine the impacts of recent increases in labour costs on profitability and inflation. Finally, we glance into the future.

\section{Recent labour shortages}

Many China watchers were surprised when reports about shortages of unskilled labour emerged in early 2004, especially in the relatively dynamic coastal region (Huang 2004). According to some reports, early that year, migrant workers in various cities of Zhejiang province fell by 10-20 per cent from a year earlier. Other reports estimated on limited data that there was a shortage of about 2 million workers in the municipalities of Guangzhou, Shenzhen and Dongguan in Guangdong province. Fujian Provincial Bureau of Statistics said that labour shortage was the reason why the average capacity utilisation rate only reached $80-85$ per cent. $^{3}$ These were scattered observations and might not be consistent with one another. But the new challenge was clear-many employers had difficulties recruiting workers.

At first sight, these shortages of unskilled workers were somewhat odd, given that there were still more than $\mathbf{3 0 0}$ million farmers in agriculture and a serious underemployment problem in the countryside seemed to remain. In retrospect, labour shortages at first reflected short-term changes in demand and supply relations. It was probably more about slow adjustment to faster growth of demand in the urban sector, instead of a decline in supply. There were probably a number of reasons why supply did not keep pace with demand at that particular period of time. First, rising food prices, which reached 15 per cent year-on-year in mid 
2004, increased income in the countryside and living costs in the cities. In fact, rural income rose by 10.6 per cent and urban consumer prices also increased by 3.6 per cent during the first half of 2004. This probably reduced the attractiveness of migrating to coastal provinces. As a result, the decline in the rural labour force slowed to -0.1 per cent in 2004 from -0.3 per cent in the previous two years, but picked up again to -0.5 per cent in 2005 .

Second, there was no efficient nationwide information network for labour demand and supply. Labour-exporting provinces did not have information about recent rapid growth in demand for migrant labour in Zhejiang, Guangdong and some other provinces. Many large employers increased efforts to recruit directly in labourexporting provinces.

Third, there were problems of skill or age mismatch. While there was still a huge unskilled surplus labour pool in the countryside, employers in the cities increasingly looked for workers with 2-3 years' experience. In fact, many employers targeted a special segment of the labour force in their recruitment-females aged between 18 and 25 . The total number of that special group in rural areas was probably no more than 70 million. And by 2004, the pool had probably been nearly exhausted, given that the total number of migrant workers had reached 100 million. Therefore, employers had to relax their age preferences if they wanted to hire more.

And, finally, though some of the migrant workers had lived in the cities for more than ten years, most of them were still denied entitlement to pension funds, medical care and education benefits due to discrimination within the household registration system. While government policies began to require employers to pay the benefits for their employees, implementation was still at a primitive stage and differed vastly among regions. Naturally, migrant workers would prefer to work in the regions where the social welfare policies were better implemented, such as in the Yangtze River Delta. Of course, the cost of labour to employers was higher when and where the expanded benefits were being paid.

Labour shortages that occurred in parts of China two years ago were temporary and could be eased by the development of labour markets. It is probably too early to conclude that China has entered a new phase of general labour shortage. But the labour shortage sent an important message to investors-that the old era of easy and abundant access to labour at low rates was coming to an end, that the total cost of labour was starting to rise, and that costs may soon start to rise quickly. In other words, the so-called 'unlimited' labour supply was probably passing into history. Going forward, the supply curve of labour was likely to be upward sloping.

As a response to the shortage problems in 2004, many employers tried various ways to attract or keep their workers. Some reimbursed employees' home-return 
trips during the Chinese New Year holiday in 2004. Others offered renminbi100 per head for referring new employees. Many raised workers' wages from renminbi1000 per month to renminbi1200-1400. As companies began to pay for regular social welfare contributions for their employees, payrolls could rise by $40-50$ per cent, including pensions (20 per cent of the payroll), health insurance ( 6 per cent), unemployment ( 2 per cent), work injury ( 1 per cent), maternity ( 0.8 per cent), and housing (5-10 per cent). ${ }^{4}$

Rising labour costs are a normal phenomenon in rapidly growing economies. Between 1975 and 2004, real manufacturing wages, measured in US dollars per hour, grew by 5.9 per cent per annum in Korea, 6.6 per cent in Taiwan, 5.8 per cent in Singapore and 5.1 per cent in Japan. Interestingly, Korea's unit labour cost rose from 5.2 per cent of that in the United States in 1975 to 49.7 per cent in 2004 (Figure 2.6). China's current unskilled labour cost, which is estimated at US $\$ 1.3$ per hour, is about 5.6 per cent of the cost in the United States. Will it take more or less years for China's labour cost to rise to half of the labour cost in the United States, than it did in Korea?

\section{Labour costs, inflation and profitability}

What has been the impact of the recent increases in labour costs on the Chinese economy? Normally, higher wages are likely to push up production costs and, therefore, either reduce profit margins or force technological upgrading. Higher labour incomes often also contribute to stronger consumer spending and generate stronger inflationary pressures. Experience over the last couple of years in China, however, has not provided strong evidence of such impact, although some new trends have started to emerge.

Chinese nominal wage rates have been growing strongly since the early stage of economic reform (Figure 2.7). Until very recently, however, nominal wage and inflation rates moved together closely, implying that real wages rates were far more stable. This relationship, however, broke down after the East Asian financial crisis. Between 2000 and 2005, nominal wage rates jumped by 14.5 per cent per annum, but consumer prices increased by only 1.3 per cent. This means that the real wage rate rose by 13.2 per cent a year. Clearly, while labour shortages became an issue in early 2004, real wage pressures started earlier, probably from as early as 1999. But wage growth has not caused an inflation problem in recent years.

When wage rates began rising alongside skyrocketing commodity prices but sluggish finished goods prices, most economists predicted a significant squeeze of profit margins for Chinese producers. Some even argued that the Chinese economy was heading to a hard landing. Contrary to the popular concerns, however, 
Figure 2.6 Growth of labour costs is a global phenomenon in rapidly growing economies (US costs $=100$ per cent)

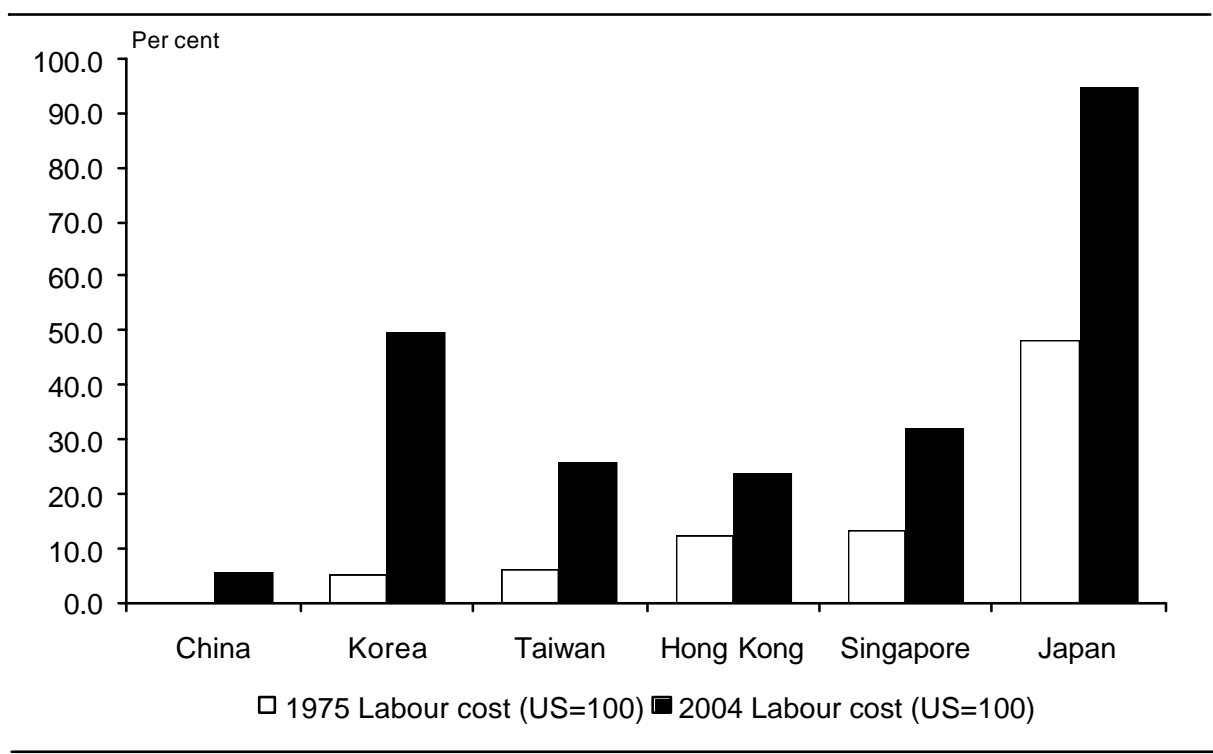

Source: United States Department of Labor.

Figure 2.7 Changing correlation between wage and inflation, 1985-2005 (per cent)

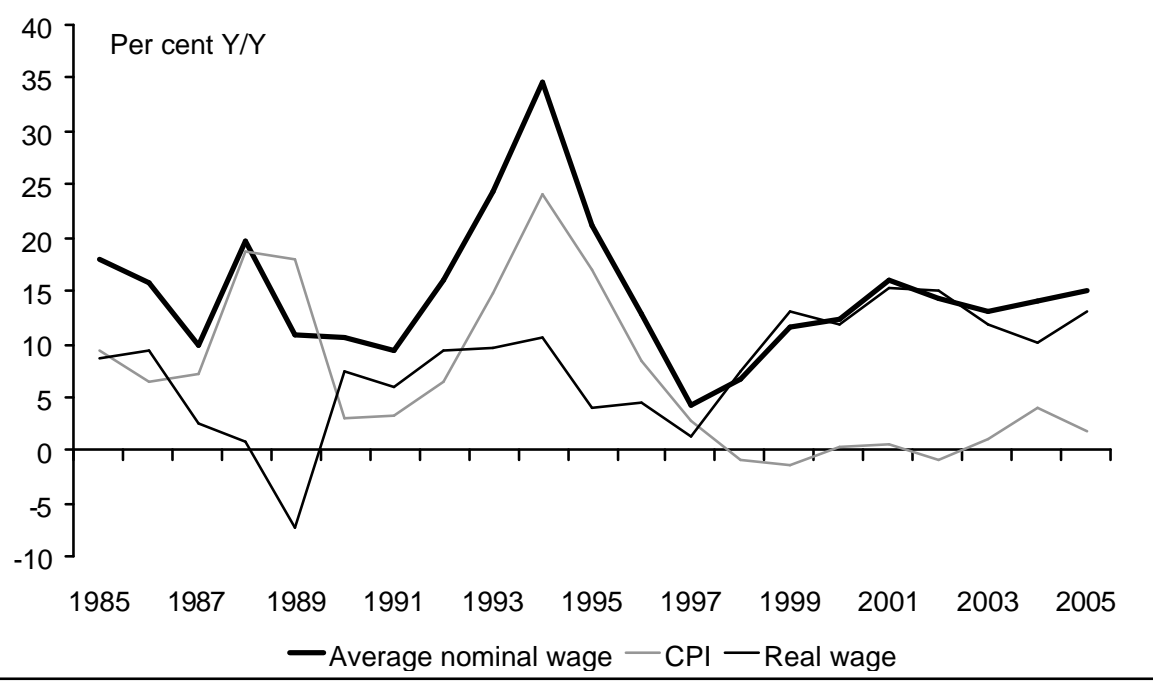

Source: CEIC Data Company. 
total industrial profits have continued to grow rapidly for the past years (Figure 2.8). Even profit margins, measured by annualised profit/asset ratios, showed no sign of a significant squeeze. In fact, the current ratio, at around 6 per cent, is still close to the highest level of the current economic cycle.

Nonetheless, disaggregated data reveal differential stories for individual sectors. Of the total 34 sectors we examined, only one industry, petroleum processing and coking, suffered negative profit margins, -2.4 per cent in 2004 and -7.5 per cent during the first five months of 2006. Petroleum and natural gas extraction, non ferrous metals mining and processing, and tobacco processing enjoyed doubledigit and rising profit rates. Profitability of most other industries remained largely stable. That of textile and electronic industries started to fall recently (Figure 2.9). The situation was similar in some other industries, such as chemical materials, timber products and furniture and rubber products. Therefore, margin squeezes are happening in selected areas.

Why have returns on investment held up so strongly despite the rapid rate of increase in unskilled wages? One reason is rapid growth in total factor productivity. A second has been a shift from more to less labour-intensive activities within each industry. Across sectors, more labour-intensive industries have shrunk relative to less labour-intensive industries. The more labour-intensive sectors (for example textiles, garments and parts of the electronics sector) are now showing signs of falling or more slowly growing returns on capital (Figure 2.9). Finally, while the cost of unskilled labour has increased, continued upgrading of the education and skill levels of the population has reduced the cost of human capital, and high savings have kept low and perhaps reduced the cost of other forms of capital. This has provided some benefit to all industries, and larger benefits towards the capital-intensive end of the spectrum.

Recent rises in labour costs have led to formulation of a new hypothesis that China could soon become an exporter of inflation. It is debatable whether export prices from one country could be a source of inflation in another country, as inflation within each country is a monetary phenomenon and should be a consequence of individual economies' monetary policies. The logic of the above hypothesis is that since China is an important exporter to global markets, higher Chinese prices could push up prices for products in markets where Chinese exports dominate. This would occur whether China chose monetary policies that achieved the required appreciation of the real exchange rate as labour becomes scarce through domestic inflation, or whether it chose policies that achieved the real appreciation through currency appreciation. 
Figure 2.8 Profit growth and profit margins in the Chinese industry, January 2001-June 2006

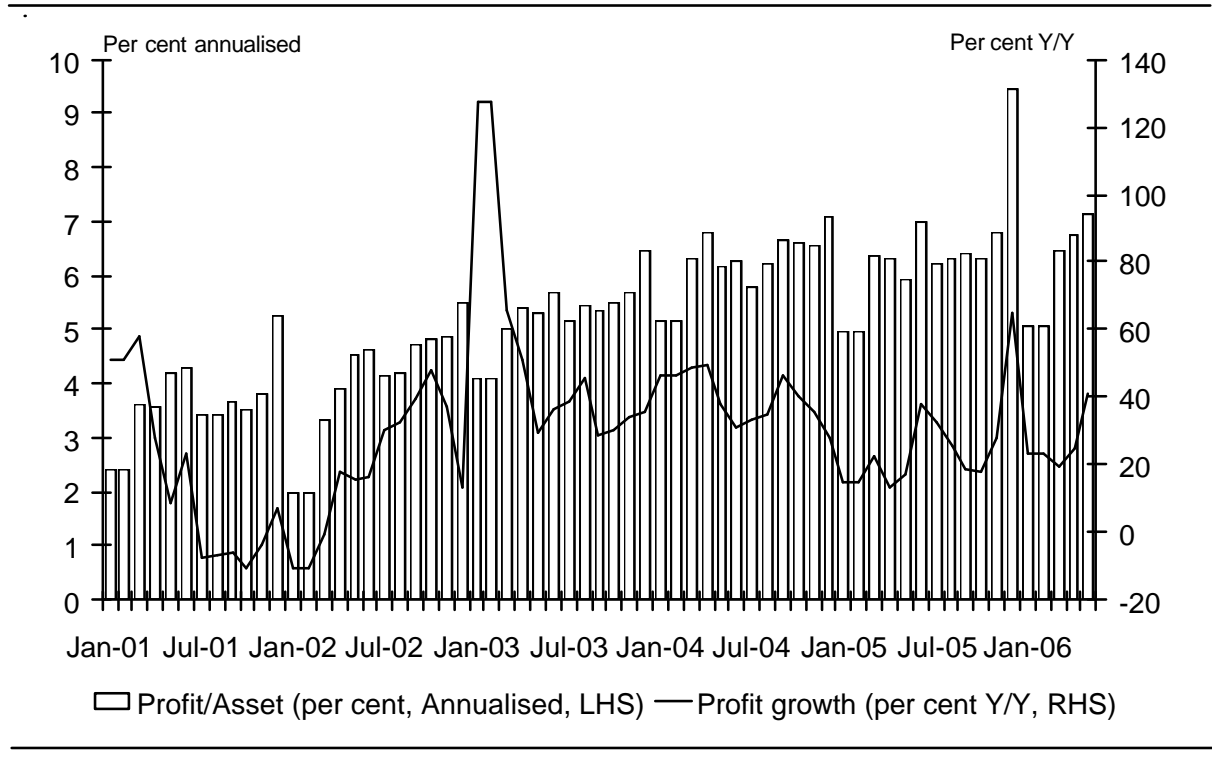

Source: CEIC Data Company.

Figure 2.9 Profit margins of selected industries, 2000-06 (per cent)

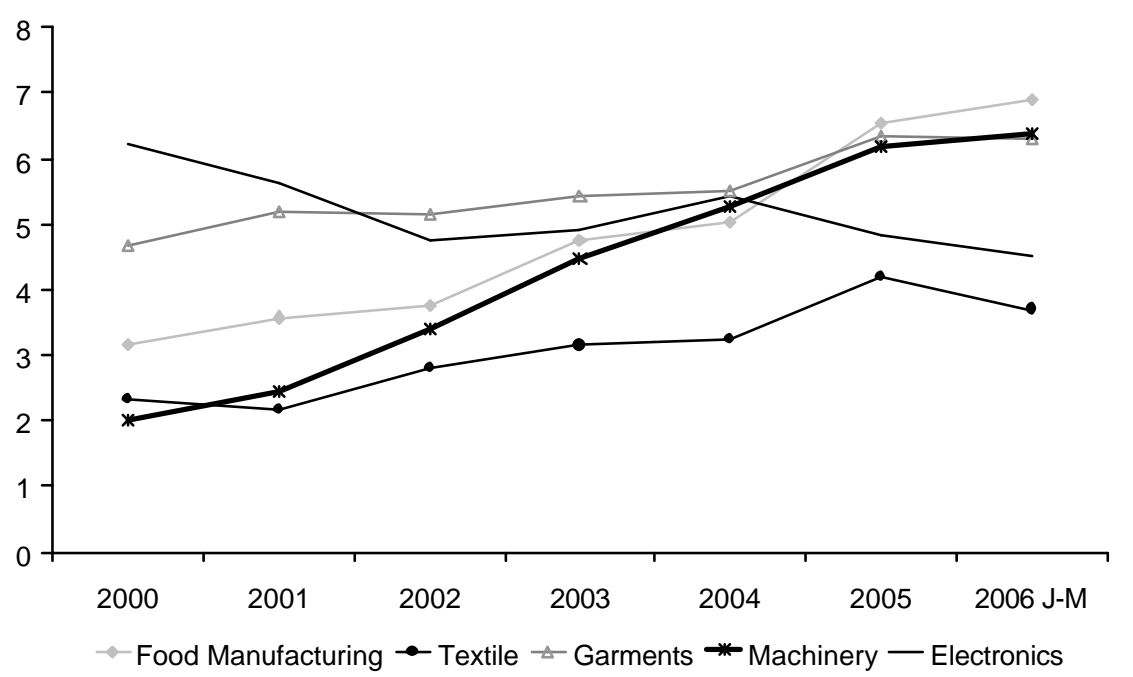

Note: 2006 J-M are based on first five months' year-on-year growth data.

Source: CEIC Data Company. 
For now, however, there is no clear evidence that China's export prices have started to rise. In fact, the index measured by United States' import prices from China shows a year-on-year decline by 1.3 per cent during the past year (Figure 2.10). Of course, in China as in countries that earlier trod along the path of exportoriented industrialisation, continued export growth is associated with increases in the quality of exports within each category of exports, and upgrading from lower value to higher value versions of similar items. It is notoriously difficult to take such matters into account in assessment of the true inflationary situation for export industries.

Of the many reasons why China's rising labour costs have shown limited general negative effects on profitability, inflation or export prices, the most important is productivity growth. If labour productivity grows faster than real wages, then producers should be able to absorb rising costs comfortably. Growth in labour productivity may take the form of technological progress, changes in product mix or increase in capital intensity. In Chinese industry, labour productivity grew much faster than real wages between 1998 and 2003. In 2004 and 2005, however, real wages outpaced productivity (Figure 2.11). This suggests that we might soon begin to see a larger impact of higher labour costs on profits, inflation and export prices in China, especially for the most labour-intensive products.

The share of employees' earnings in total value-added basically tells a similar story (Figure 2.12). In the period 2000-04, labour cost's share declined consistently, implying declines in labour cost per unit of output. But the share took a drastic upturn from the beginning of 2005. It will be interesting to see whether this important structural change signals the beginning of a new paradigm.

That an international investment response to rising labour costs in China has already commenced is evident in statements from major global exporters of textiles, garments, electronics and other labour-intensive goods in 2006. The Managing Director of Fung and Fung in Hong Kong, for example, in August 2006 is reported on Bloomberg business news services as saying that rising labour costs were causing them to shift the sourcing of labour-intensive products and components from coastal China, to the inland of China, South Asia and Southeast Asia.

\section{A glance into the future}

Experiences of the past couple of years suggest that China's economic development has reached an important turning point-the ending of so-called unlimited labour supply - even though the impact of rising labour costs on inflation and profitability are limited in extent. Such changes in the labour market can be expected to accelerate significantly in the coming years. 
Figure 2.10 China's export prices, January 2005-May 2006

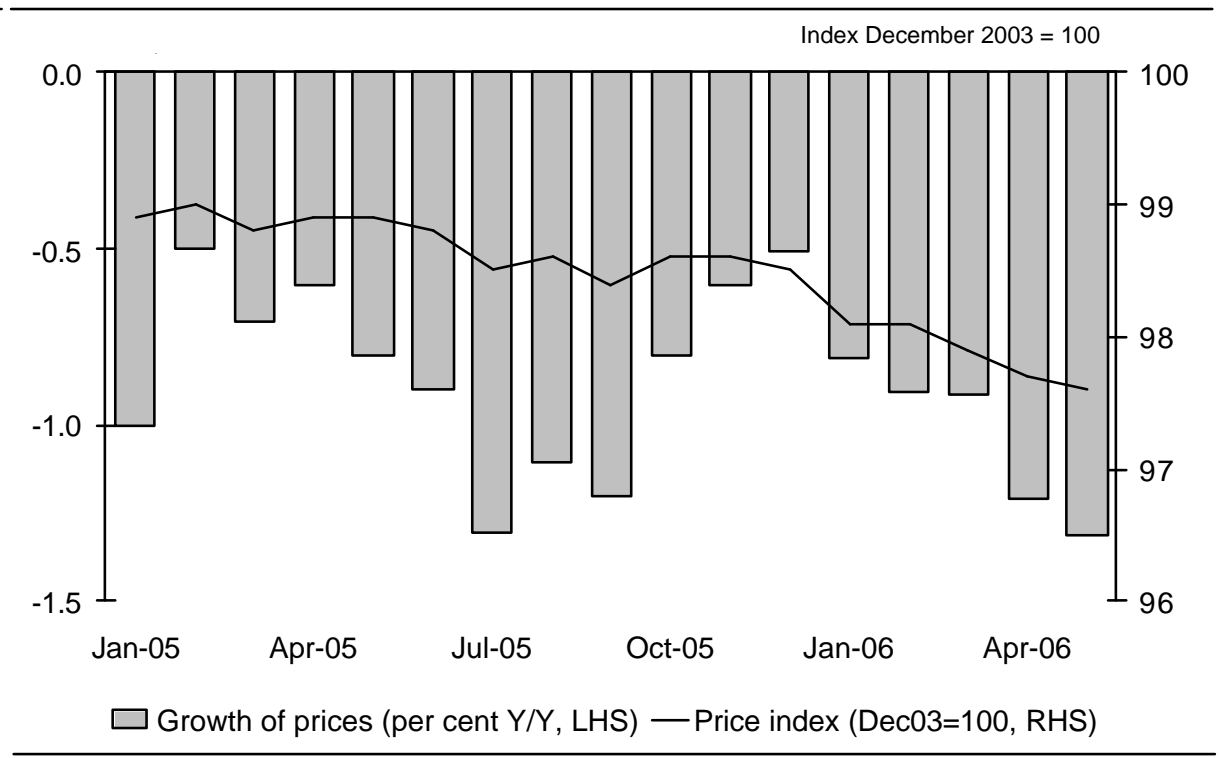

Source: CEIC Data Company.

Figure 2.11 Labour productivity growth and increases in real wages in China, 1998-2005 (per cent)

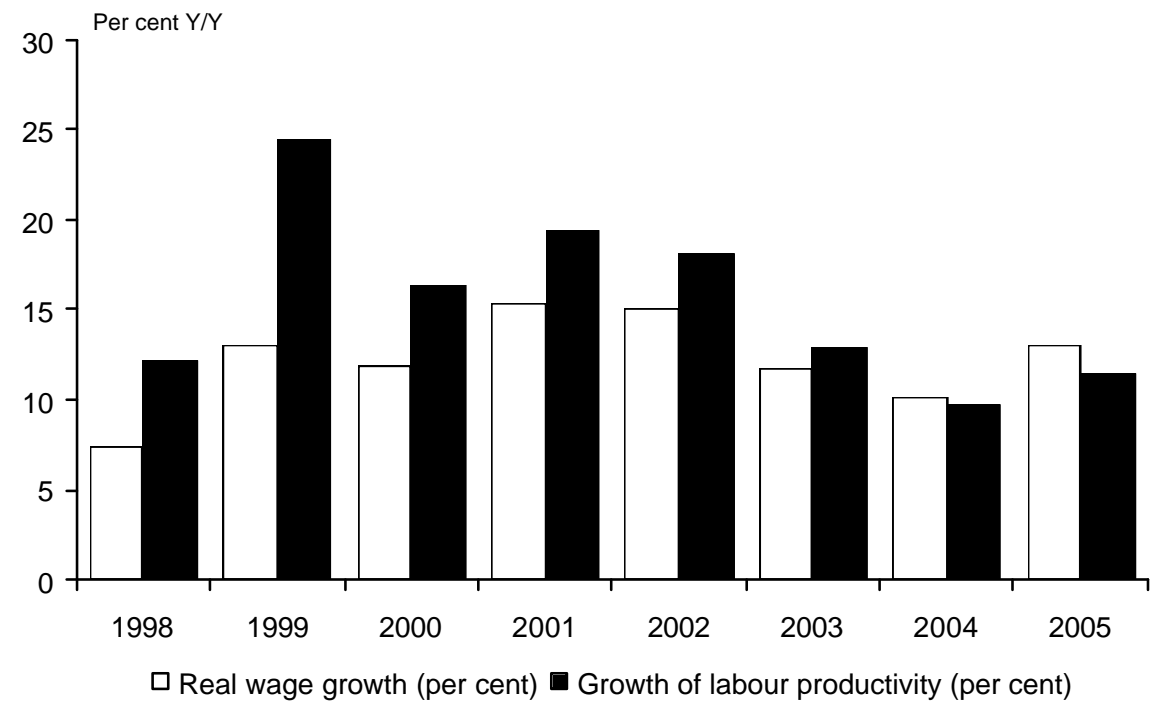

Source: CEIC Data Company. 
A closer look at the supply and demand for relatively unskilled labour suggests that there is likely to be a considerable tightening in the market in the period ahead-larger and earlier than has featured in the general discussion of China's economic prospects, within China or abroad. The balance between supply and demand for and the cost of skilled and managerial labour will not be subject to as much tension, where supplies are being expanded rapidly by formal education, on-the-job training and experience, and the demonstration effects through the ubiquitous presence of foreign enterprises.

Growth of China's total labour force has already slowed markedly, from 3 per cent per annum in the 1980s to 1 per cent in the period 2000-05, as the effects of the one-child policy of the reform period have moved through into the working-age population. Until recently, migration of workers to meet the requirements of strong urban employment growth slowed growth of rural employment only moderately. Between 2000 and 2005, however, the rural labour force declined by 0.9 per cent (Figure 2.13). This raises productivity of rural labour at home, and can be expected to put strong upward pressure on rural labour costs. This raises the supply price of migrant labour to urban areas.

The opposing changes in agricultural versus non-agricultural (inclusive of urban and rural non-agricultural) employment were more profound (Figure 2.14). These changes are likely to accelerate in the coming years. Over time, as the rural labour force shrinks and the urban labour force expands, a given rate of increase in urban labour demand represents a continuously increasing proportion of the pool of rural labour from which migrants are drawn, both because the denominator is shrinking, and the numerator is increasing. Higher and higher wages can be expected to recruit the same number of workers, and yet the required number of additional workers will increase each year.

Looking ahead, according to the Asian Demographics Ltd, China's total labour force may also start to decline from 2010 (Figure 2.15). Between 2009 and 2020, the number of Chinese workers may decline by an average of 4.3 million workers a year, or 0.6 per cent per annum.

The decline in supply of labour will be more dramatic for unskilled labour, due to the combination of a decline in the total labour force and improving education levels of the population. The number of people with education up to completed primary school had already declined from 645 million in 1990 to 494 million in 2004 (see Figure 12.6). According to Asia Demographics Ltd, this number can be expected to fall further to 268 million by 2020 . The absolute numbers of unskilled workers available for labour-intensive tasks in industry, construction and services will fall much more rapidly than the labour force in total, at a time when the absolute 
Figure 2.12 The share of employees' earnings in total industrial valueadded, Q1 2000-Q1 2006 (per cent)

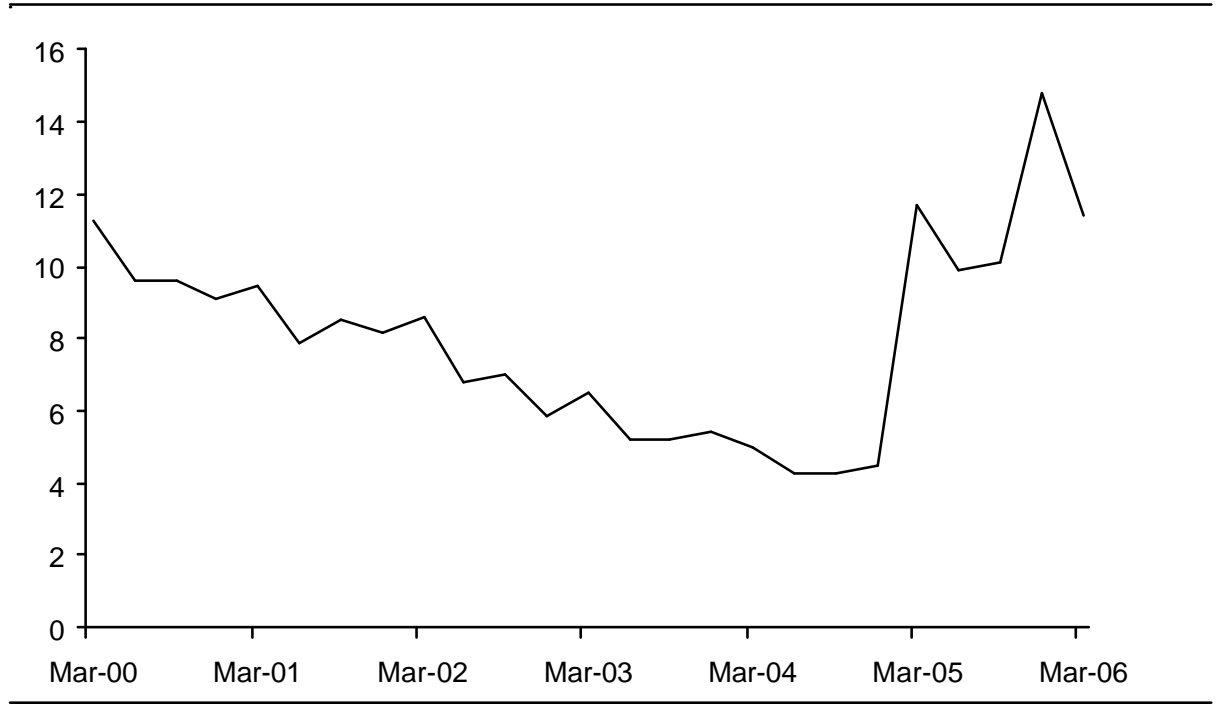

Source: CEIC Data Company.

Figure 2.13 Recent decline in rural employment, 1991-2005 (per cent of total employment)

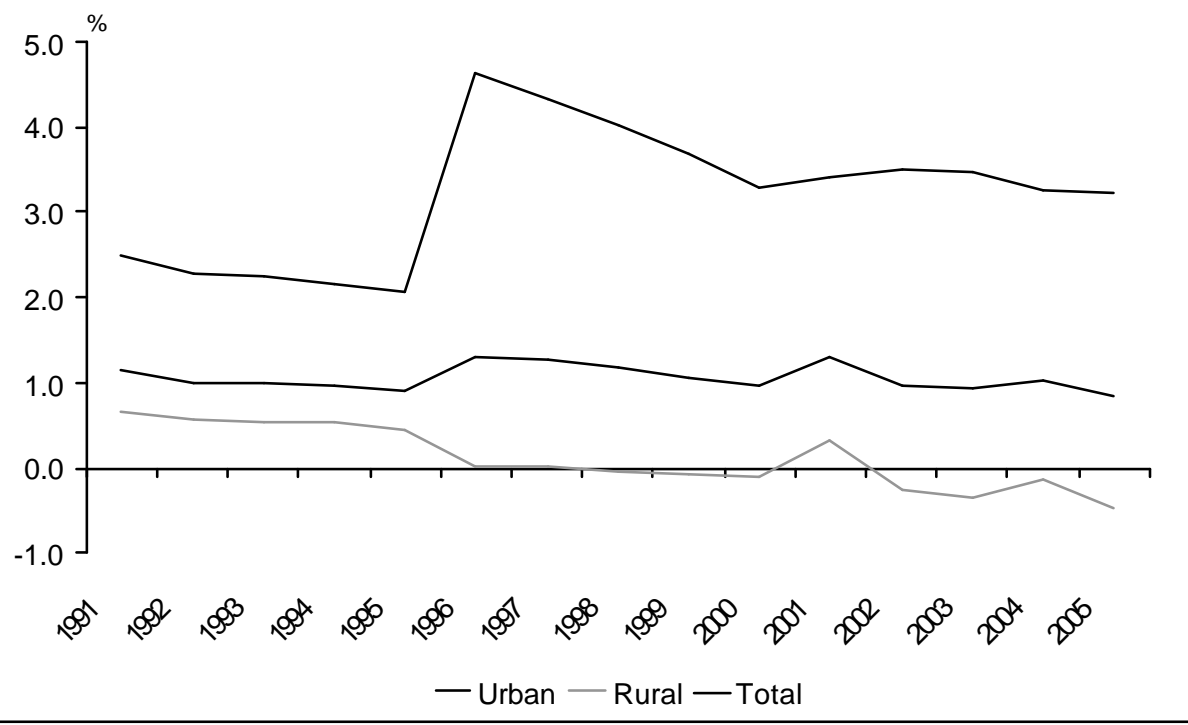

Source: CEIC Data Company. 
Figure 2.14 Declines in agricultural employment, 1991-2005 (per cent of total employment)

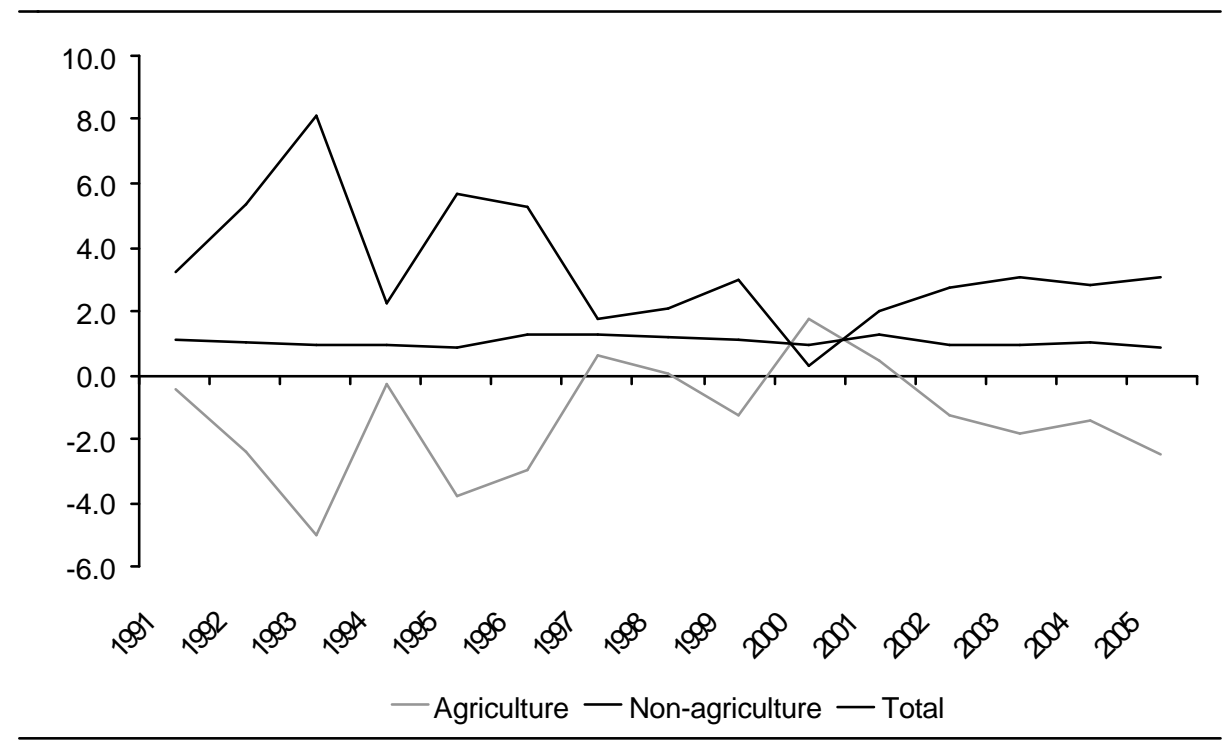

Source: CEIC Data Company.

Figure 2.15 Changes in China's labour force, 1990-2020

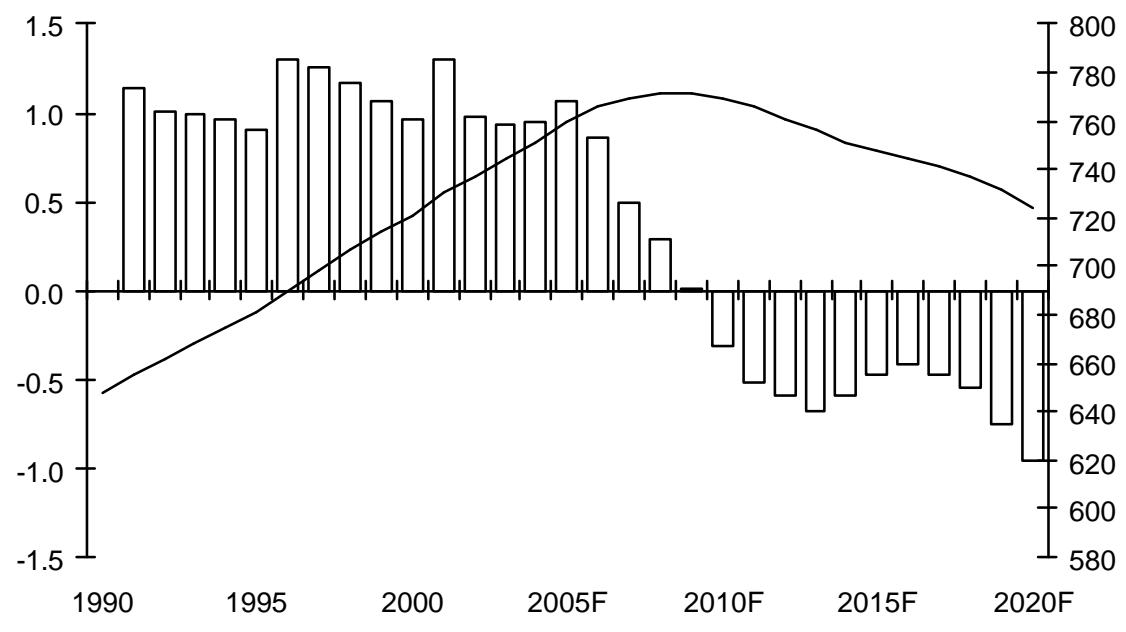

$\square$ Growth of labour force (per cent, LHS) — Total labour Force (Million, RHS)

Source: Asia Demographic Limited. 
Figure 2.16 Improving levels of education of the Chinese population, 1982-2020

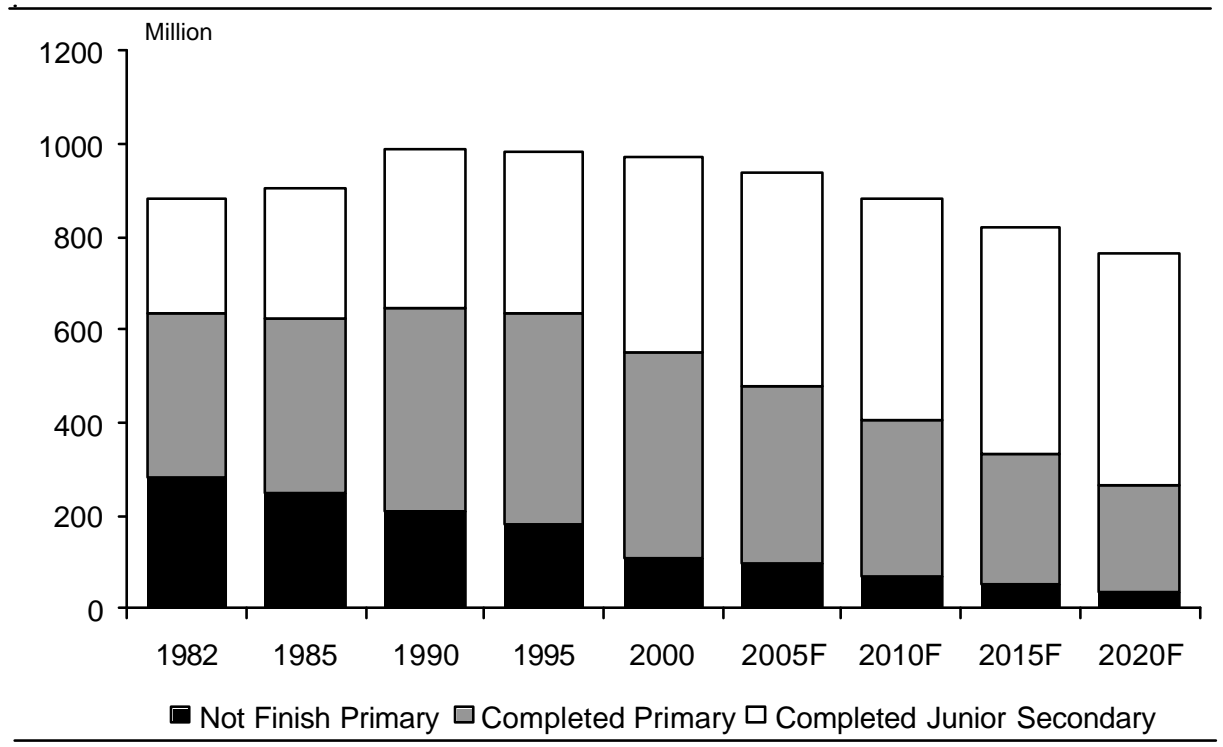

Source: Asia Demographic Limited.

size of the annual increase in demand for labour will be rising rapidly—unless it was moderated by rapidly rising wages.

Recent official wage data also support the view that China is moving toward the turning point. On average, urban wages increased faster than GDP during the past five or six years, pointing to rising share of labour compensation in GDP. More interestingly, although wages are still quite low in the labour-exporting provinces, such as Sichuan, their growth has been faster than in typical labourimporting provinces, such as Guangdong and Shanghai (Table 2.1). The supply price of labour from the inland regions to the coastal cities is rising, at the same time as demand growth is placing upward pressure on urban wages.

Sector-wise, wage growth has been led by mining and financial industries. Wages for agricultural and construction workers grew at a similar pace. Construction workers are mostly temporary migrant farmers, and their wages reflect the rising opportunity cost of labour from rural areas (Table 2.2).

The quality of education is rising, as increasing education expenditure is allocated to a student population that is declining at the lower levels and growing only 
Table 2.1 Average wage rates by region, 1999-2006e (yuan constant 1999 prices and per cent per annum growth)

\begin{tabular}{lrrrrrrrr}
\hline & Beijing & Liaoning & Shanghai & Zhejiang & Hubei & Guang Dong & Sichuan & Ningxia \\
1999 & 14,450 & 8,037 & 16,690 & 11,208 & 6,972 & 12,311 & 7,246 & 7,477 \\
2000 & 16,317 & 8,889 & 18,428 & 13,044 & 7,546 & 13,875 & 8,414 & 8,679 \\
2001 & 19,194 & 10,199 & 20,962 & 16,082 & 8,556 & 15,686 & 9,919 & 10,476 \\
2002 & 21,788 & 11,911 & 22,406 & 18,365 & 9,604 & 17,747 & 11,097 & 11,731 \\
2003 & 24,477 & 13,130 & 25,144 & 20,461 & 10,426 & 19,616 & 12,128 & 12,994 \\
2004 & 27,504 & 14,163 & 26,658 & 21,630 & 11,082 & 20,783 & 13,132 & 13,967 \\
2005 & 31,079 & 16,025 & 29,301 & 23,454 & 12,793 & 22,078 & 14,464 & 16,292 \\
$2006 E$ & 36,845 & 18,729 & 32,354 & 25,461 & 14,729 & 23,661 & 16,071 & 19,062 \\
Growth & & & & & & & \\
1
\end{tabular}

Note: $2006^{\mathrm{e}}$ are estimates based on the first quarter data. Beijing, Shanghai, Guangdong and Zhejiang are from the dynamic coastal region ; Liaoning from the old industrial Northeast; Hubei from central China; and Sichuan and Ningxia from the Southwest and West respectively.

Source: CEIC Data Company.

slowly at higher levels of education. This expansion of the stock of human capital will facilitate the rapid diversification of Chinese industrial structure into more technologically complex activities.

\section{Concluding remarks}

The recent labour shortage probably signaled the beginning of the end to the 'unlimited' supplies of labour. It came earlier than was economically necessary because of imperfections in labour markets, and improvements in the market can ameliorate these effects for a while. But there will be no avoiding the implications of the supply curve for labour becoming steeply upward sloping.

Average real wages grew by 13 per cent per annum during the past five years.

So far, wage inflation has had limited impacts on profitability, inflation and export prices. The key factor contributing to muted macroeconomic implication in the near term was rapid economy-wide growth of productivity. Structural change towards more capital-intensive processes and industries also played an important role.

This may change soon, as, according to our estimation, real wage growth had already outpaced improvement in labour productivity in 2004 and 2005. The share of workers' compensation in total industrial value-added also surged from 2005. 
Table 2.2 Average annual wage rates for agriculture, manufacturing, construction and finance, 1978-2004 (yuan constant 1999 prices and per cent per annum increase)

\begin{tabular}{llrrrrr}
\hline & Agriculture & Mining & Manufacture & Construction & Wholesale and Retail Finance \\
1985 & 2,895 & 4,365 & 3,666 & 4,491 & 3,320 & 3,805 \\
1986 & 3,244 & 4,857 & 3,947 & 4,755 & 3,554 & 4,189 \\
1987 & 3,297 & 4,797 & 4,090 & 4,858 & 3,663 & 4,206 \\
1988 & 3,108 & 4,768 & 4,152 & 4,756 & 3,778 & 4,222 \\
1989 & 2,859 & 4,894 & 3,910 & 4,458 & 3,416 & 3,842 \\
1990 & 3,075 & 5,424 & 4,137 & 4,758 & 3,628 & 4,185 \\
1991 & 3,189 & 5,679 & 4,419 & 5,113 & 3,824 & 4,353 \\
1992 & 3,317 & 5,823 & 4,781 & 5,563 & 3,999 & 5,133 \\
1993 & 3,231 & 5,871 & 5,297 & 5,979 & 4,238 & 5,917 \\
1994 & 3,594 & 5,965 & 5,461 & 6,240 & 4,509 & 8,557 \\
1995 & 3,835 & 6,268 & 5,628 & 6,299 & 4,625 & 8,031 \\
1996 & 4,072 & 6,518 & 5,673 & 6,283 & 4,687 & 8,452 \\
1997 & 4,216 & 6,683 & 5,803 & 6,509 & 4,739 & 9,520 \\
1998 & 4,464 & 7,140 & 6,965 & 7,351 & 5,783 & 10,484 \\
1999 & 4,832 & 7,521 & 7,794 & 7,982 & 6,417 & 12,046 \\
2000 & 5,164 & 8,307 & 8,716 & 8,701 & 7,162 & 13,425 \\
2001 & 5,679 & 9,482 & 9,668 & 9,382 & 8,104 & 16,101 \\
2002 & 6,381 & 10,987 & 10,971 & 10,251 & 9,372 & 19,083 \\
2003 & 6,867 & 13,482 & 12,313 & 11,310 & 10,779 & 22,128 \\
2004 & 7,217 & 16,000 & 13,307 & 12,109 & 12,254 & 25,585 \\
Growth & & & & & & \\
$2000-04$ & 8.7 & 17.8 & 11.2 & 8.6 & 14.4 & 17.5 \\
\hline & & & & & & \\
\hline
\end{tabular}

Source: CEIC Data Company.

More importantly, demographic transition implies that China may soon face much more serious supply constraint in the labour market, especially for unskilled workers, in rural as well as urban areas.

With these developments, we are likely to see major transition in the pattern of Chinese economic growth. The dynamic coastal regions will graduate surprisingly quickly from labour-intensive activities and re-specialise in capital- or technologyintensive sectors of the production process. In the absence of currency appreciation, inflation rates would start to rise. Higher real wages would lead to higher rates of increase in consumer spending. Rising opportunity cost of labour in the countryside and wages in towns would be helpful in containing the increase in income inequality-a source of growing tension and concern. It would also increase the self confidence and bargaining power of labour, and lead to pressures 
for improved conditions of work across a wide range of issues, and in the absence of thoughtful management responses, to increased industrial unrest.

A few factors may also cushion the economic impact of the turning point. Productivity growth is likely to remain strong in the Chinese economy. Reform of the household registration system, which has been carried out in some provinces this year, reduces transaction costs of migration and can increase potential supply to the urban economy (see Du, Gregory and Meng, Chapter 10).

How would growing labour scarcity and higher wages affect Chinese economic growth and relations with the international economy?

Growth need not slow, until China is approaching the frontiers of global productivity and incomes-and in the best of circumstances that approach is a couple of decades away. With falling labour supply and rising wages, China will rely on continued capital intensification - human capital and capital in other formsand total factor productivity growth. Capital intensification will continue to be supported by high savings rates and the value that society places on educationalthough the quality of policy in the education sector will affect outcomes. Total factor productivity growth is already reasonably high (see Wang, Chapter 3), and will be encouraged by continuation of high levels of direct foreign investment, and by structural change driven by rising labour costs themselves. The condition for continued rapid productivity growth is that China is structurally flexible, investing heavily in the infrastructure, human capital and other capital required to support profitable knowledge-based industries, and accepting the decline of labour-intensive industries and processes as they are rendered obsolete in a labour-scarce economy. Inevitably, these developments will make much larger demands on the free flow of economic and other information, and free movement of people within China and across its borders.

The diversification of Chinese exports away from simple labour-intensive goods, towards technologically complex and capital-intensive goods and services, has already begun. At first, this reduces protectionist resistance to Chinese export growth in the rest of the world, which, within the manufacturing sector, is strongest in labour-intensive goods. Global markets are deeper for more complex manufactures, which will assist adjustment to rapid Chinese export growth. However, the scale of the increase in Chinese trade will be so large in absolute terms that areas of trade that are now subject to minimal protectionist intervention will come to be seen as sensitive in much of the rest of the world. For China and its trading partners, to give in to these pressures would be to forgo opportunities for continuing improvement in material conditions. This adds to the importance of ensuring now that we have an effective, rules-based international trading system. 
China's rapidly growing trade and current account surpluses are currently a source of tension with trading partners. In themselves, rising wages and consumption will help to correct the imbalances, but too slowly and incompletely to reduce the urgency of accelerated adjustment in the nominal exchange rate. Timely appreciation will ease the path for rapid growth of the wider range of manufactured exports that will accompany the turning point. It will also ensure that the increase in real costs through the turning period does not take the form of destabilising inflation.

Monetary policy choices will determine whether the increased scarcity of labour, as China goes through the turning point, comes out as a stronger currency or as inflation. Either way, the cost of labour-intensive Chinese goods, but possibly not other Chinese exports, will rise. Either way, Chinese incomes, as measured by standard national accounts and converted at current exchange rates, will rise much more rapidly relative to other countries than simple comparisons of growth rates across countries would suggest. China will move towards the average incomes of the high-income countries much more rapidly than is generally expected. That has been the case with all other successful Northeast Asian economies at and beyond the turning point of economic development. China will not be a special and different case.

\section{Acknowledgments}

The authors are indebted to Ligang Song for analytic contributions to our discussion of the turning point in economic development. The views expressed in this chapter are those of the authors and do not necessarily represent views of the organisations they are associated with.

\section{Notes}

1 According to the Research Center for Rural Economy under the Ministry of Agriculture, however, total number of migrant workers reached 98 million at the end of November 2003 and has been growing at 5 per cent year-on-year since then. In addition, a survey of 2600 firms in 26 cities by the Ministry of Labour and Social Security shows the number employed migrant labour up 13 per cent in 2004 from a year ago.

2 'Manufacturers attracted to China with low wages, WTO admission', Washington Post, 27 November 2001.

3 For reports in the Chinese media, see, for instance, an article on Southern Weekend on 15 July 2004, at http://finance.tom.com/1001/1002/2004715-74213.html

4 These estimates are from Zhai Fan, formerly an official of the Ministry of Finance. 